\title{
USE OF AHP AND MOORA FOR CATTLE BREEDING: KARESI DISTRICT OF BALIKESIR PROVINCE APPLICATION
}

\author{
Ramazan DEMIR, TR1010553 Livestock Business, Balıkesir, Turkey, ramazandemirr666@gmail.com \\ (iD) https://orcid.org/0000-0001-6258-1283) \\ Özlem KUVAT*, Business Management, Faculty of Economics and Administrative Sciences, Balıkesir University, Turkey, \\ ohasgul@balikesir.edu.tr ( ${ }^{-1 D}$ https://orcid.org/0000-0001-7017-4557)
}

Received: 05.09.2019, Accepted: 07.02.2020

*Corresponding author

Research Article

DOI: $10.22531 /$ muglajsci.616054

\begin{abstract}
The enterprises within the cattle sector, which holds an important place in the development of agriculture and animal husbandry sector, have to make decisions about their production frequently. These farm animals are categorized into three categories: dairy, meat and combined (meat and dairy). In line with these characteristics, business owners make production with their chosen animals. Enterprises face problems as a result of irregularities in the market, supply and demand imbalance, insufficient research by the investors and breeding of farmers towards breeds that are not suitable for their purposes. In this study, it was aimed to determine which breed would be appropriate for the breeding enterprises. This study was carried out in Ballkesir Province due to its high production potential in terms of agriculture and animal husbandry. Karesi District, which has an important share in production in Ballkesir Province, has been considered as the application area. In the study, between 50-100 and over 100 bovine farms are considered. In this study, important criteria were determined for enterprises and comparison of these criteria was provided. A hierarchical system was used to compare the criterias "Vital Characteristics", "Milk Yield Characteristics" and "Meat Yield Characteristics", according to the opinions of business owners or managers, and to select the most suitable alternative. According to the established decision model; Analytic Hierarchy Process (AHP) method was used in order to determine the criteria priorities and Multi-Objective Optimization on the basis of Ratio Analysis (MOORA) method was used to sort the alternatives

Keywords: Multi Criteria Decision Making, AHP, MOORA, Livestock Enterprises, Selection of cattle breeds
\end{abstract}

\section{BÜYÜKBAŞ HAYVAN IRKI SEÇIMİ IÇIIN AHP VE MOORA KULLANIMI: BALIKESIR İLİ KARESİ İLÇESİ UYGULAMASI}

\section{Özet}

Tarım ve hayvancılık sektörünün gelişmesinde önemli bir yer tutan büyük baş hayvancıllk sektörü içinde yer alan işletmeler yaptıkları üretimle ilgili sık sık karar almak durumunda kalmaktadır. Bu işletmelerde yetişsirilen kültür ırkları süt, et ve kombine (et ve süt) ırklar olarak üç kategoride sınıflandırılmaktadır. İşletme sahipleri bu özellikler doğrultusunda seçim yaptıkları ırk üzerinden üretim yapmaktadırlar. Piyasada meydana gelen düzensizlikler, arz talep dengesizliği, yatırımcıların yetersiz araştırma yapmaları ve yetiştiricilerin amaçlarına uygun olmayan ırklar üzerine yönelmeleri sonucunda işletmeler sorunlar yaşamaktadırlar. Bu çalışmada büyükbaş hayvan yetiştiren işletmelerin hangi ırka yönelik seçimler yapmasının uygun olabileceğinin belirlenmesi amaçlanmıştır. Çalışma tarım ve hayvancılık açısından yüksek üretim potansiyelinin bulunmasından dolayı Balıkesir İlinde gerçekleştirilmiştir. Balıkesir İli içerisinde üretimde önemli bir payı bulunan Karesi İlçesi uygulama bölgesi olarak dikkate alınmıştır. Çalışmada 50-100 arası ve 100 üstü büyükbaş hayvan varlığına sahip olan ișletmeler dikkate alınmıștır. İşletmeler için önemli kriterler belirlenmiş ve bu kriterlerin kıyaslanması sağlanmıştır. İşletme sahiplerinin ya da yöneticilerin kendi düşünceleri doğrultusunda "Yaşamsal Özellikler", Süt Verimi Özellikleri” ve "Et Verimi Özellikleri” kriterleri açısından klyaslama yapması ve en uygun alternatifin seçilmesi için hiyerarşik bir sistem kullanılmıştır. Kurulan karar modeline göre; kriter önceliklerinin belirlenmesinde AHP Analitik Hiyerarşi Prosesi (AHP) ve alternatiflerin sıralanmasında Oran Analizi Temeline Dayalı Çok Amaçlı Optimizasyon (MOORA) yöntemleri kullanılmıştır.

Anahtar Kelimeler: Çok kriterli karar verme, AHP, MOORA, Hayvancılık işletmeleri, Büyükbaş hayvan ırkı seçimi

Cite

Demir, R., Kuvat Ö., (2020). “Use of Ahp and Moora for Cattle Breeding: Karesi District of Balıkesir Province Application”, Mugla Journal of Science and Technology, 6(1), 8-17. 


\section{Introduction}

Animal products, especially meat, milk and dairy products; has become an important trade product in domestic and inter-provincial domestic market. Decisions to be taken in medium and long-term planning are of particular importance in order to avoid difficulties in the production and marketing of animal products. It is one of these decisions that the enterprises choose the animal breeds to be raised. In making this choice, the enterprises consider some criteria. This problem is suitable to be evaluated as a multi-criteria decision making problem. With this study, it is aimed to determine the priority values of the criteria that the enterprises consider and to sort the animal breeds by considering the values of these criteria. In the study, AHP method was used to determine the significance of the criteria and MOORA method was used to rank alternative animal breeds. In addition, another purpose of the study to obtain results that can be benefited by enterprises and related institutions that raise cattle in both local and national-international areas. According to the results, both enterprises and policy makers will be able to consider these results in long-term planning.

Few studies have been carried out in the literature for the use of decision making methods and breed selection in solving problems faced by livestock enterprises. Tano et al. (2003) investigated the preferences of farmers for cattle characteristics in West Africa by conjoint analysis [1]. Wasike et al. (2010) evaluated the factors affecting the efficiency of the registration system of meat and dairy cattle in Kenya by SWOT-AHP analysis [2]. Küçükönder, Efe and Üçkardeş (2013) rated holstein, simental, brown and jersey for the best milk yield in terms of the first calving age, lactation rank and calving season criterias using AHP. Their ranking was holstein, simental, brown and jersey [3]. Alitaneh et al. (2015), suggested feeding the G-coded animal after deciding between 10 alternatives considering milk production rate, fat $\%$, protein $\%$, body weight and somatic cell counts criteria by using AHP and Delphi methods [4]. Kariuki et al. (2017) used AHP, one of the multi-criteria decision-making methods, to achieve consensus of the desired genetic gains for dairy cattle breeding purposes [5].

An important difference of this study from the other studies is that "Vital Characteristics", "Milk Yield Characteristics" and "Meat Yield Characteristics" criteria are evaluated as sub-criteria in itself and compared in detail and the discussion of MOORA method which has not been used in ranking of cattle breeds and their characteristics in literature.

The study being carried out by taking the views of a very large breeder group in the Karesi District of Balıkesir Province into account which has an important position for Turkey in terms of husbandry is another contribution.
In the second part of the study, commonly found breeds in Turkey has been introduced. In the third part of the study, Analytic Hierarchy Process and MOORA methods, which are multi-criteria decision making methods, are examined in detail and in the fourth chapter, the practice made in Karesi district of Balıkesir Province is included. In the fifth section, the results are evaluated.

\section{Common Animals Bred In Turkey}

Breeds are examined in three parts as dairy, combined (meat and milk) and meat. In order to meet the increasing human needs, its been attempted to create more efficient animals through breeding. In recent years, breeding projects and pure breed protection efforts have been made to increase yields. This study includes common breeds in Turkey and in Balıkesir [6].

- $\quad$ Ayrshire: It is of Scottish origin. Its color is red and white mottled. It has a medium size. The adult weight is around $544 \mathrm{~kg}$. Calves are healthy and easy to grow [6].

- Jersey: Their homeland is the island of Jersey between England and France. Brought to Turkey from America and placed in the Black Sea region. Their colors range from light brown to dark brown. They are not much affected by hot weather. However, meat yields are low. They are small, cute and sensitive. They have the biggest feed to milk ratio and they have a very fatty milk [7]. The Jersey breed is physically the smallest built of dairy breeds. It consumes $25 \%$ less feed compared to other breeds and it is an excellent breed in converting the feed it consumes [8].

- Montafon-Brown Swiss: This breed has been bred pure in Switzerland for 1000 years. It is the first breed brought to Turkey. The cultivation was started in 1925 immediately after the declaration of the Republic. The total number of pure breeds and hybrids in the country is around 2.7 million. It was first brought to the Karacabey studfarm in Bursa and spread to the region by crossbreeding with pure breeds [6].

- $\quad$ Simental: The homeland of the Simental breed is Switzerland. It has been developed as a result of longterm breeding and selection of low-yield breeds throughout the country. It has spread to many foreign countries, especially Germany, and the breeding work has continued, and it ranks first among cattle breeds in Germany. It is a preferred bovine genotype worldwide due to meat deficiency. It was initially imported to Turkey from Hungary during the first years of the republic, but was abandoned after the breeding work. In the 1970s, it was re-imported and started breeding activities [6].

- Holstein: The Holstein breed is a breed developed in the Netherlands under good conditions for feeding and cool climatic conditions. Its adaptability to the warm climate and poor maintenance and feeding conditions is not good. In addition, this breed has spread to many countries of the world due to its high milk yield 
and good meat yield [9]. Raising of holstein cattle in Turkey began in 1958. 30 female and 17 male Holstein calves were brought from America and a Holstein herd was established in Karacabey. The first breeders were distributed to the Marmara and Aegean regions by artificial insemination and used in the hybridization of the animal breeds in this region. This new breed with new yield characteristics caused public sympathy. Imports of this breed from United States, the Netherlands and Germany (in order) continues [6]. This race is physically black and white colored and appear in sharp contrast. It is the largest built among other milk breeds. Although it ranks first in terms of milk yield, it has low values in terms of fat and protein [10].

- $\quad$ Shorthorn: The colors are usually red-gray. Red and white ones are also encountered. It has a high impact on world cattle farming. They develop early and live weight increases are high [8].

\section{Multi Criteria Decision Making}

The decision-making problem can be defined as choosing one of the alternative groups. The selection process is carried out by considering the criteria [11]. Multiple criteria in some decision making problems may increase complexity. In addition, in the case where these criteria contradict each other, the values of some criteria may improve while the others deteriorate [12].

Multi Criteria Decision Making (MCDM) includes a process for selecting the most appropriate one among the alternatives. Alternatives in such problems are evaluated by joint judgment of different criteria [13]. It is not always easy to make a choice by evaluating multiple alternatives considering multiple criteria. Therefore, techniques such as AHP, Electre, VIKOR, MOORA, TOPSIS, PROMETHEE are used to assist the decision maker [14]. In this study, AHP was used to compare the criteria and MOORA was used to list the alternatives.

\subsection{AHP}

In the AHP method, firstly, the inter-factor comparison matrix (A) is created. This matrix is a square matrix nxn dimensions [15]. A one-to-one comparison of the factors uses the Saaty's scale of importance. [16]. The use of numbers from 1 to 9 is recommended in this scale. 1 corresponds to equal importance; 9 represents absolute superiority [17]. Then the normalization of the binary comparison matrix is provided and the line averages of the normalized matrices give the priority vector (priority values) w. To check the consistency, the vector $w$ is multiplied by the binary comparison matrix $A$ and the $A w$ matrix is obtained. The $\lambda_{e n b}$ eigenvalues are calculated by summing the values in the $A w$ matrix . Here, the consistency ratio is determined as given in $C R$ Equation (1) [18].

$$
C R=((\lambda e n b-n) /(n-1)) / R I
$$

The $R I$ value is a random index value. It has a 0.58 value when matrix size is $3,0.90$ value when matrix size is 4 and 1.12 value when matrix size is 5 . For the consistency to be valid, this ratio value should be less than $10 \%[15,19]$.

\subsection{MOORA}

As one of the multi-criteria decision making methods; The Multi-Objective Optimization on the basis of Ratio Analysis (MOORA) method was developed in 2006 by Brauers and Zavadskas. Although this method is new, it has become a highly preferred method in recent years. The MOORA method is an effective method for making the most accurate decisions to solve various and complex problems that are difficult for decision making. The method is easy and usable with both comparing the results and presenting measurable values $[20,21]$.

When the MOORA method is classified as literature; it can be specified as The MOORA-Ratio Method, the MOORA Importance Coefficient, the MOORA-Reference Point Approach, the MOORA-Full Multiplicative Form and the Multi-MOORA. Generally used MOORA method; Ratio Method and Reference Point Approach method are applied in two parts. If desired, while both methods are used, it may be preferred to use a single method. The method consists of rows and columns. Rows consist of alternatives, while columns consist of criteria [22].

Compared to other multi-criteria decision making methods, MOORA is superior to other methods on taking all criteria into consideration. It evaluates all interactions between decision options and criteria as a whole rather than one by one. The method is more advantageous than other methods for using nonsubjective independent values method instead of subjectively normalizing [21].

During the implementation phase, the decision matrix is created first. In the decision matrix (X) rows, there are alternatives where their advantages are to be listed, and the evaluation criteria in the columns are $i=1,2, \ldots, m$ (alternative) and $j=1,2, \ldots, n$ (criteria) are listed as given in Equation (2) [23].

$$
X=\left[\begin{array}{cccc}
x_{11} & x_{12} & \ldots & x_{1 n} \\
x_{21} & x_{22} & \ldots & x_{2 n} \\
\vdots & \vdots & \vdots & \vdots \\
\vdots & \vdots & \vdots & \vdots \\
x_{m 1} & x_{m 2} & \ldots & x_{m n}
\end{array}\right]
$$

After the decision matrix is formed, normalization is applied and then operations for sequencing are performed. In the normalization process, each value for the criterion $\mathrm{i}=1,2,3, \mathrm{~m}$ alternative, and $\mathrm{j}=1,2, . . n$ is divided by the square root of the sum of squares as given in Equation (3) [22, 24].

$$
x_{i j}{ }^{*}=\frac{x_{i j}}{\sqrt{\sum_{i=1}^{m} x_{i j}^{2}}}
$$

When the normalization process table is created, according to the ratio method; As given in Equation (4), the values of the maximum directional criteria are added for each alternative to subtract the values of the minimum directional criteria from this sum [20]. 


$$
Y i=\sum_{j=1}^{g} x_{i j}{ }^{*}-\sum_{j=g+1}^{n} x_{i j}{ }^{*}
$$

Here, $g$ represents the number of criteria to be maximized and $n-g$ represents the number of criteria to be minimized, while $Y i$ indicates the normalized value for the alternative. If a criterion is to be weighted, the corresponding ratio can be multiplied by the weight value of that criterion. Equation (5), which is the equality used in this case, is given below [25].

$$
Y i=\sum_{j=1}^{g} w_{j} * x_{i j}{ }^{*}-\sum_{j=g+1}^{n} w_{j} * x_{i j}{ }^{*}
$$

Then, sorting is done according to the results obtained.

\section{Cattle Breeding In Karesi District Of Balıkesir}

Balikesir, Turkey has an important place in agriculture and animal husbandry. Geographical location, ease of transportation, ports, climatic conditions and large companies in terms of market makes the region important. The most important feature that separates the region is that raw milk and meat products are found to be of high quality by the raw material supply companies and consumers.

Balikesir, in Turkey; for cattle, it ranks 3rd in the number of animals and milk production in the culture cattle. In addition, it ranks 4 th in bovine milk production and ranks 5th in the total number of cattle and total bovine animals. According to 2018 data; There are 538.682 bovine animals in the province and 714.119 tons of milk was produced [26].

$3.7 \%$ of bovine presence in Turkey is available in Balikesir. There are close to 500.000 cattle in the province, the largest share of which is the cattle. Large rangelands in the province, is one of the factors that affect the development of livestock activities. Most of the bovine animals in Balıkesir are culture breeds. The districts where dairy cattle breeding stands out; Altıeylül, Karesi, Bigadiç, Susurluk, Gönen and İvrindi; districts where meat cattle production is prominent are Susurluk, Bigadiç, Altıeylül and Karesi [27].

Karesi District is a district with one of the highest animal husbandry potentials in Turkey and in Balıkesir. During the implementation period, to the Karesi Governorship District Food, Agriculture and Livestock Directorate, there are 2812 livestock enterprises in the district and a total of 53681 bovine animals are bred in these enterprises [28].These figures are indicative of the importance of production potential of the region. The use of numerical methods at decision-making points in order to increase the efficiency of business owners by using their resources in the most effective way will be the guiding tools for them.

In this study, an application has been made in order for the business owners to choose the most suitable breed in line with their own opinions and to make the regional policies more successful.

\subsection{Research Model}

According to the research, enterprises in Karesi District were divided into three groups according to their size: small-scale enterprises with 50 sub-cattle; 50-100 cattle with medium-sized businesses; and large-scale companies with over 100 cattle and more.

In the study, between 50-100 and over 100 bovine farms are considered as an expert group. Due to the low number of cattle and milk production, transportation difficulties and the high number of cattle, less than 50 cattle enterprises were excluded from the application. There are 132 enterprises with 50-100 cattle in the region. A total of 132 enterprises were tried to be reached but as a result of the breeders who could not be found in the enterprise and non-return enterprises, a total of 73 enterprises could be surveyed. There are 28 enterprises with 100 or more bovine animals and all of them were reached and a survey was conducted.

According to the calculation made based on the ratio in determining the sample size; considering $0.10 \alpha$ meaning level and e error margin and $\mathrm{p}$ and $\mathrm{q}$ ratios as 0.5 , the required sample size is 68 questionnaires according to the formula given in Equation 6 [29]. 73 samples taken in the study correspond to $9 \%$ error margin.

$$
n=\frac{z_{\frac{\alpha}{2}}^{2} \cdot p \cdot q}{e^{2}}
$$

\begin{tabular}{|c|c|c|c|}
\hline & & $\begin{array}{c}50-100 \\
\text { frequency }\end{array}$ & $\begin{array}{l}100 \text { or more } \\
\text { frequency }\end{array}$ \\
\hline \multirow{2}{*}{$\begin{array}{c}\text { Structural } \\
\text { feature of the } \\
\text { enterprise }\end{array}$} & Family & 73 & 18 \\
\hline & Company & & 10 \\
\hline \multirow{3}{*}{$\begin{array}{l}\text { Type of } \\
\text { business }\end{array}$} & Milk & 1 & 1 \\
\hline & Meat & 8 & 3 \\
\hline & Mixed & 64 & 24 \\
\hline
\end{tabular}

The properties of the enterprises are given in Table 1.

All medium-sized enterprises are family enterprises. When the types of enterprises are examined, $87.7 \%$ is a mixed enterprise while $11 \%$ is meat and $1.4 \%$ is dairy.

Large enterprises; in terms of structural characteristics, $35.7 \%$ is large-scale companies, while $64.3 \%$ is family enterprises. The type of farms is $85.7 \%$ mixed farms, $10.7 \%$ meat farms and $3.6 \%$ dairy farms.

There are a total of 4888 cattle in 73 farms with 50-100 cattle in the scope of the research conducted in the district of Karesi. In terms of breed distribution; there are 3021 holstein, 898 simental, 513 hybrid, 302 montafon, 82 various cattle and 72 jersey breeds. There are a total of 7986 cattle in 28 enterprises with 100 or more cattle. In terms of breed distribution; there are 5606 holstein, 1215 simental, 363 hybrid, 439 montafon, 363 various cattle breeds. The similarity or 
difference of this distribution with the suggestions to be obtained after the analysis results is one of the prominent elements of the study.

In the study, firstly AHP hierarchy was established and criteria and sub-criteria were determined for animal breed selection. In order to perform AHP analysis, comparison matrices were formed.

In this study, three main criteria were determined such as "Vital Characteristics", "Milk Yield Characteristics" and "Meat Yield Characteristics" in AHP hierarchy which was designed to make suitable breed selections for cattle breeding enterprises. 5 sub-criteria for vital characteristics, 4 sub-criteria for milk yield characteristics and 3 sub-criteria for meat yield characteristics were evaluated.
The expert group was asked to compare the criteria mutually. For example; The "Average Life Time" criterion is rated with 5 significance levels if it has 'essential or strong importance' according to the "Difficult Birth Rate" criterion. But; the "Difficult Birth Rate" criterion is rated as $1 / 5$ if it has 'essential or strong importance' according to the "Average Life Time" criterion. Because of this calculation, the geometric mean of each comparison score was taken as a result of the comparison.

The established hierarchy is given in Figure 1.

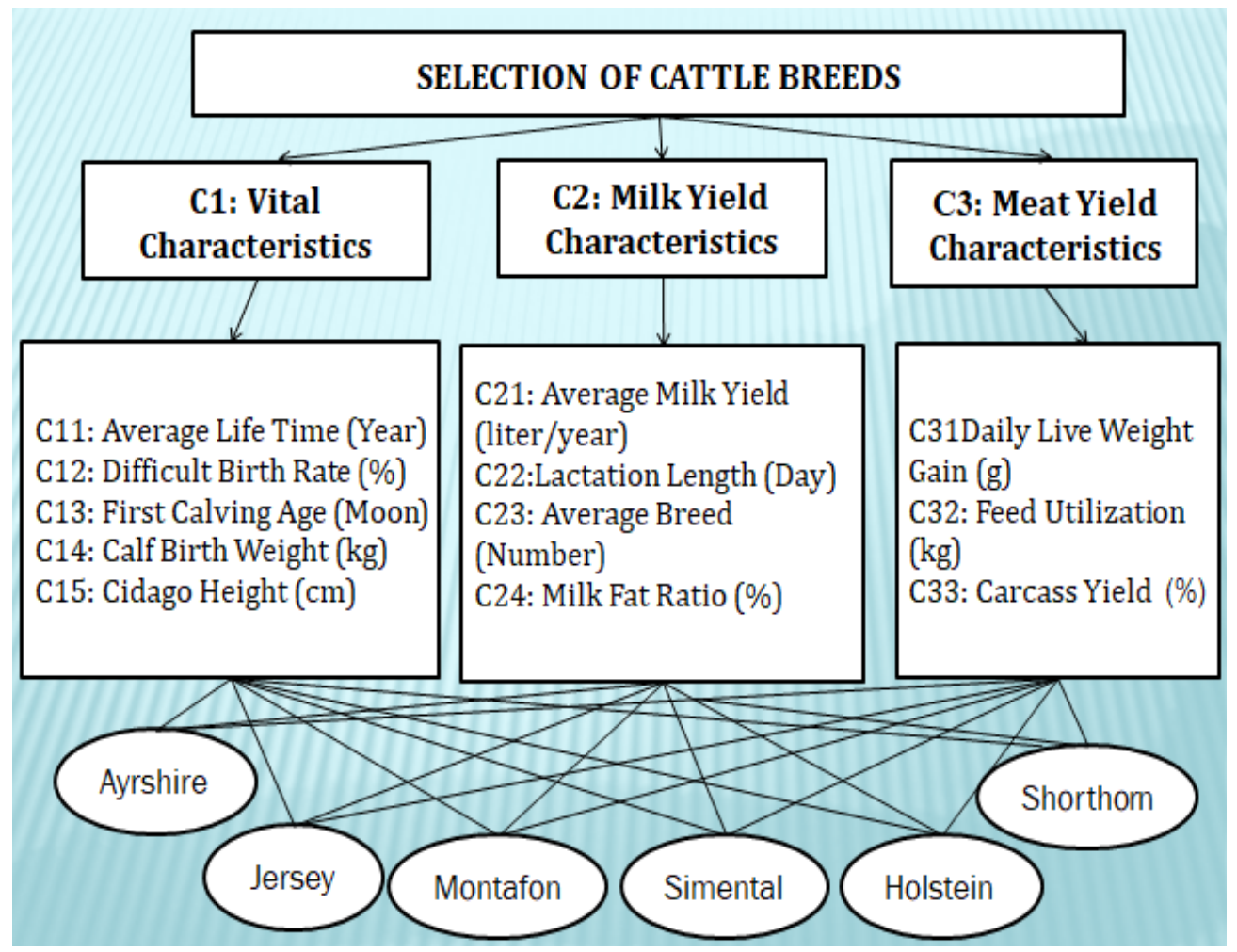

Figure 1. Selection hierarchy model

In the study, the suggestions for choosing among the alternative breeds were presented by considering the local and global weight values obtained as a result of the comparison of the criteria and sub-criteria. The opinions of breeders were benefited from to determine the criteria and alternatives. The evaluation was then carried out with MOORA to rank the alternatives (Ayrshire, Jersey, Montafon-Brown Swiss, Simental:, Holstein, Shorthorn).

In the study, after the creation of the AHP hierarchy model, the characteristics of the cattle breeds, namely alternatives, were evaluated according to the criteria considered. After defining the characteristics, the maximization (max) and minimization (min) directions were determined according to whether these characteristics are desired to be of high value. The normalized values of the properties calculated according to Equation (3) are given in Table 2. Interviews with breeders in the preparation of this table were the sources for the publications of Inal et al. (2016), Uğur (2004) and Demsa Genetik, Koç (2016: 104) and HAYGEM publications [6, 8, 30, 31, 32].This table was then used for sequencing with MOORA. 
Table 2. Culture breeds and yield characteristics normalized values

\begin{tabular}{cllcccccc}
\hline Direction & Code & \multicolumn{1}{c}{ Criteria } & Ayrshire & Jersey & Montafon & Simental & Holstein & Shorthorn \\
\hline max & C11 & Average Life Time & 0.369 & 0.389 & 0.410 & 0.410 & 0.491 & 0.369 \\
$\min$ & C12 & Difficult Birth Rate & 0.370 & 0.313 & 0.427 & 0.513 & 0.427 & 0.370 \\
$\max$ & C13 & First Calving Age & 0.469 & 0.375 & 0.422 & 0.422 & 0.375 & 0.375 \\
$\min$ & C14 & Calf Birth Weight & 0.390 & 0.228 & 0.430 & 0.456 & 0.488 & 0.406 \\
$\min$ & C15 & Cidago Height & 0.402 & 0.359 & 0.416 & 0.430 & 0.436 & 0.402 \\
$\max$ & C21 & Average Milk Yield & 0.362 & 0.312 & 0.469 & 0.428 & 0.500 & 0.344 \\
$\max$ & C22 & Lactation Length & 0.407 & 0.407 & 0.407 & 0.414 & 0.434 & 0.380 \\
$\max$ & C23 & Average Breed & 0.300 & 0.360 & 0.480 & 0.360 & 0.540 & 0.360 \\
$\max$ & C24 & Milk Fat Ratio & 0.378 & 0.503 & 0.358 & 0.397 & 0.436 & 0.358 \\
$\max$ & C31 & Daily Live Weight Gain & 0.382 & 0.297 & 0.382 & 0.573 & 0.382 & 0.382 \\
$\max$ & C32 & Feed Utilization & 0.427 & 0.463 & 0.356 & 0.285 & 0.463 & 0.427 \\
$\max$ & C33 & Carcass Yield & 0.378 & 0.348 & 0.422 & 0.447 & 0.385 & 0.458 \\
\hline
\end{tabular}

\subsection{Breed Selection for Enterprises with 50-100 Cattle}

In order to perform AHP analysis, comparison matrices were formed at first. After the comparison, the geometric mean values were divided by the sum of the columns to normalize. Priority values are determined by taking the average of the normalized values. Priority sequences were then determined and consistency control was provided.

The comparison matrix and priority (importance) vector (PV) values of the main criteria are given in the table below.

Table 3. Comparison Matrix

\begin{tabular}{|c|c|c|c|c|}
\hline & J & ป઼ & חુ & $\vec{z}$ \\
\hline $\begin{array}{l}\text { C1 Vital } \\
\text { Characteristics }\end{array}$ & 1.00 & 1.89 & 0.66 & 0.35 \\
\hline $\begin{array}{l}\text { C2 Milk Yield } \\
\text { Characteristics }\end{array}$ & 0.53 & 1.00 & 0.87 & 0.26 \\
\hline $\begin{array}{l}\text { C3 Meat Yield } \\
\text { Characteristics }\end{array}$ & 1.52 & 1.14 & 1.00 & 0.39 \\
\hline Total & 3.05 & 4.03 & 2.53 & 1.00 \\
\hline
\end{tabular}

According to the obtained results, the most important criterion among the main criteria for 50-100 cattle owners is meat yield with a priority value of 0.39 , secondly with vital characteristics with a value of 0.35 and milk yield with a value of 0.26 .

When sub-criteria are taken into consideration; according to the importance vector values obtained as a result of normalization made considering vital characteristics; the average life expectancy takes the first place with 0.43 . The average birth rate for milk yield characteristics is considered to be the primary criteria priority with a result of 0.50 .

As a result of normalization made considering meat yield characteristics; according to the importance vector obtained, Daily live weight gain is the most important criterion with a significance level of 0.44 .

The global weight can be calculated as follows: Global Weight for Daily Live Weight Gain = Importance level for Meat Yield Characteristics * Importance level for Daily Live Weight Gain $=0.44 * 0.39=0.1716$.

When the global weights are taken into consideration, the highest value is Daily live weight gain with 0.17 , followed by Average Life Time with 0.15 degree and Carcass yield with 0.14 level.The values of the obtained local and global weights are presented in Table 4 and Figure 2 in the graph. 
Table 4. Criteria global weights of businesses (50-100)

\begin{tabular}{clllll}
\hline & Code & Sub-criterion & PV & $\begin{array}{l}\text { Global } \\
\text { Weights }\end{array}$ & Rank \\
\hline \multirow{2}{*}{ Main criteria } & C1 & Vital Characteristics & 0.35 & & \\
CR=0.08 & C2 & Milk Yield Characteristics & 0.26 & & \\
& C3 & Meat Yield Characteristics & 0.39 & & \\
\hline Vital & C12 & Average Life Time & 0.43 & 0.15 & 2 \\
Characteristics & C13 & Fifficult Birth Rate & 0.32 & 0.11 & 5 \\
CR=0.06 & C14 & Calf Birth Weight & 0.16 & 0.05 & 8 \\
& C15 & Cidago Height & 0.06 & 0.02 & 10 \\
Milk Yield & C21 & Average Milk Yield & 0.04 & 0.01 & 11 \\
Characteristics & C23 & Lactation Length & 0.34 & 0.09 & 6 \\
CR=0.07 & C24 & Milk Fat Ratio & 0.11 & 0.03 & 9 \\
& C31 & Daily Live Weight Gain & 0.44 & 0.13 & 4 \\
Meat Yield & C32 & Feed Utilization & 0.20 & 0.01 & 12 \\
Characteristics & C33 & Carcass Yield & 0.37 & 0.08 & 7 \\
CR=0.06 & & & 0.14 & 3 \\
\hline
\end{tabular}

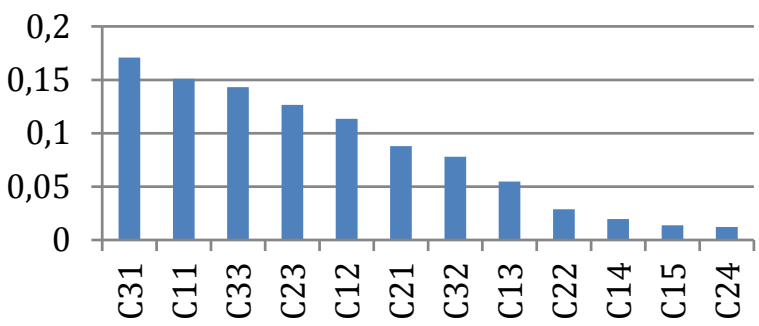

After determining the global weights of criterions for 50-100 cattle breeding enterprises, it was ensured to rank the animal breeds by MOORA ratio method. For this purpose, sequencing were performed by using the formulas in Equation (4) and Equation (5).

Obtained ratio values and sequence information is given in the table below.

Figure 2. Global Weights (50-100)

Table 5. Ranking of breeds with MOORA (50-100)

\begin{tabular}{|c|c|c|c|c|c|c|c|c|}
\hline Weight & & Criteria & Ayrshire & Jersey & Montafon & Simental & Holstein & Shorthorn \\
\hline 0.15 & $\max$ & C11 & 0.369 & 0.389 & 0.410 & 0.410 & 0.491 & 0.369 \\
\hline 0.11 & $\min$ & $\mathrm{C} 12$ & 0.370 & 0.313 & 0.427 & 0.513 & 0.427 & 0.370 \\
\hline 0.05 & $\max$ & C13 & 0.469 & 0.375 & 0.422 & 0.422 & 0.375 & 0.375 \\
\hline 0.02 & $\min$ & C14 & 0.390 & 0.228 & 0.430 & 0.456 & 0.488 & 0.406 \\
\hline 0.01 & $\min$ & C15 & 0.402 & 0.359 & 0.416 & 0.430 & 0.436 & 0.402 \\
\hline 0.09 & $\max$ & $\mathrm{C} 21$ & 0.362 & 0.312 & 0.469 & 0.428 & 0.500 & 0.344 \\
\hline 0.03 & $\max$ & $\mathrm{C} 22$ & 0.407 & 0.407 & 0.407 & 0.414 & 0.434 & 0.380 \\
\hline 0.13 & $\max$ & $\mathrm{C} 23$ & 0.300 & 0.360 & 0.480 & 0.360 & 0.540 & 0.360 \\
\hline 0.01 & $\max$ & $\mathrm{C} 24$ & 0.378 & 0.503 & 0.358 & 0.397 & 0.436 & 0.358 \\
\hline 0.17 & $\max$ & C31 & 0.382 & 0.297 & 0.382 & 0.573 & 0.382 & 0.382 \\
\hline 0.08 & $\max$ & $\mathrm{C} 32$ & 0.427 & 0.463 & 0.356 & 0.285 & 0.463 & 0.427 \\
\hline \multirow[t]{3}{*}{0.14} & $\max$ & C33 & 0.378 & 0.348 & 0.422 & 0.447 & 0.385 & 0.458 \\
\hline & & Ratio & 0,2658 & 0,2629 & 0,2956 & 0,2972 & 0,3197 & 0,2771 \\
\hline & & Rank & 5 & 6 & 3 & 2 & 1 & 4 \\
\hline
\end{tabular}


For example, for the holstein alternative; firstly, the normalized value of the maximized directional criteria and the priority values of the criterion were calculated and weighted. Then, the weighted values were maximized. $(0.15 * 0.491+0.05 * 0.375 \ldots . .0 .14 * 0.385)$ Similarly; the normalized value of the minimized directional criteria and the priority values of the criterion were calculated and weighted. Weighted values were also collected for minimization criteria. $(0.11 * 0.427+0.02 * 0.488+0.01 * 0.436)$. For each alternative, the difference between the ratio value was calculated (0.3808-0.061). The ratio value obtained was 0.3197. Sorting among the alternatives was made according to the ratio value.

According to the sequence information obtained; Holstein is the first; Simental is the second and Montafon is the third.

\section{Breed Selection for Enterprises with 100 or More Cattle}

A dual comparison matrix was first designed for the AHP survey of 100 cattle owners in the Karesi district of
Balıkesir. According to the importance vector obtained as a result of normalization made by comparing the main criteria; with the importance level of 0.62 , vital characteristics appeared to be the most important criteria. The life expectancy with 0.52 value is the most important criterion among the vital characteristics. Difficult birth rate ranks second with 0.24 importance vector. For milk yield characteristics; the average milk yield is the most important criterion with an importance level of 0.47. According to the importance vector obtained for meat yield characteristics; Carcass yield is the most important criterion with a importance level of 0.46. When global weights are evaluated; The life expectancy with a importance level of 0.32 is very significant compared to other criteria. Difficult birth rate with a rate follows it with 0.15 and average milk yield shares the third rank with carcass yield of 0,09 . The values for the obtained local (PV) and global weights are presented in Table 6 and Figure 3.

Table 6. Criteria global weights of businesses (100 and above)

\begin{tabular}{|c|c|c|c|c|c|}
\hline & Code & Sub-criterion & PV & $\begin{array}{c}\text { Global } \\
\text { Weights }\end{array}$ & Rank \\
\hline \multirow{3}{*}{$\begin{array}{c}\text { Main criteria } \\
\quad C R=0,06\end{array}$} & $\mathrm{C} 1$ & Vital Characteristics & 0.62 & & \\
\hline & $\mathrm{C} 2$ & Milk Yield Characteristics & 0.19 & & \\
\hline & $\mathrm{C} 3$ & Meat Yield Characteristics & 0.19 & & \\
\hline \multirow{5}{*}{$\begin{array}{c}\text { Vital } \\
\text { Characteristics } \\
\text { CR=0,09 }\end{array}$} & C11 & Average Life Time & 0.52 & 0.32 & 1 \\
\hline & $\mathrm{C} 12$ & Difficult Birth Rate & 0.24 & 0.15 & 2 \\
\hline & C13 & First Calving Age & 0.14 & 0.08 & 5 \\
\hline & C14 & Calf Birth Weight & 0.06 & 0.04 & 8 \\
\hline & C15 & Cidago Height & 0.04 & 0.03 & 9 \\
\hline \multirow{4}{*}{$\begin{array}{c}\text { Milk Yield } \\
\text { Characteristics } \\
\text { CR }=0,09\end{array}$} & $\mathrm{C} 21$ & Average Milk Yield & 0.47 & 0.09 & 3 \\
\hline & $\mathrm{C} 22$ & Lactation Length & 0.13 & 0.02 & 11 \\
\hline & $\mathrm{C} 23$ & Average Breed & 0.36 & 0.07 & 6 \\
\hline & $\mathrm{C} 24$ & Milk Fat Ratio & 0.04 & 0.01 & 12 \\
\hline \multirow{3}{*}{$\begin{array}{c}\text { Meat Yield } \\
\text { Characteristics } \\
\text { CR=0,07 }\end{array}$} & C31 & Daily Live Weight Gain & 0.36 & 0.07 & 7 \\
\hline & C32 & Feed Utilization & 0.18 & 0.03 & 10 \\
\hline & C33 & Carcass Yield & 0.46 & 0.09 & 4 \\
\hline
\end{tabular}

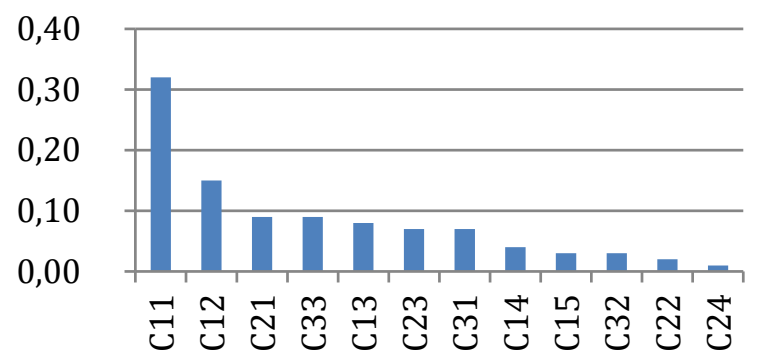

Figure 3.Global Weights (100 and above)
Following the determination of the global weights of criterions for enterprises with 100 or more cattle, it was ensured to rank the animal breeds by MOORA ratio method.

According to the sequence information obtained; Holstein is the first; Montafon is the second and Simental is the third.

Obtained ratio values and sequence information is given in the table below.

Table 7: Ranking of breeds with MOORA (100 and above) 


\begin{tabular}{ccccccccc}
\hline Weight & & Criteria & Ayrshire & Jersey & Montafon & Simental & Holstein & Shorthorn \\
\hline 0.32 & max & C11 & 0,369 & 0,389 & 0,410 & 0,410 & 0,491 & 0,369 \\
0.15 & min & C12 & 0.369 & 0.389 & 0.410 & 0.410 & 0.491 & 0.369 \\
0.08 & max & C13 & 0.370 & 0.313 & 0.427 & 0.513 & 0.427 & 0.370 \\
0.04 & $\min$ & C14 & 0.469 & 0.375 & 0.422 & 0.422 & 0.375 & 0.375 \\
0.03 & min & C15 & 0.390 & 0.228 & 0.430 & 0.456 & 0.488 & 0.406 \\
0.09 & max & C21 & 0.402 & 0.359 & 0.416 & 0.430 & 0.436 & 0.402 \\
0.02 & max & C22 & 0.362 & 0.312 & 0.469 & 0.428 & 0.500 & 0.344 \\
0.07 & max & C23 & 0.407 & 0.407 & 0.407 & 0.414 & 0.434 & 0.380 \\
0.01 & max & C24 & 0.300 & 0.360 & 0.480 & 0.360 & 0.540 & 0.360 \\
0.07 & max & C31 & 0.378 & 0.503 & 0.358 & 0.397 & 0.436 & 0.358 \\
0.03 & max & C32 & 0.382 & 0.297 & 0.382 & 0.573 & 0.382 & 0.382 \\
0.09 & max & C33 & 0.427 & 0.463 & 0.356 & 0.285 & 0.463 & 0.427 \\
& & Ratio & 0,211 & 0,220 & 0,234 & 0,222 & 0,262 & 0,212 \\
& & Rank & 6 & 4 & 2 & 3 & 1 & 5 \\
\hline
\end{tabular}

\section{Conclusion}

While businesses make breed selection for cattle they are raising, they make a selection by joint evaluating meat and milk production. Enterprises may face problems as a result of irregularities in the market, supply and demand imbalance, insufficient research by the investors and breeders' inability to select suitable breed. In this study, it was aimed to determine which breed would be appropriate for the business through surveys conducted on the cattle breeding enterprises in the Karesi District of Ballkesir Province. According to the global weights obtained by AHP analyzes for the enterprises that have 50 - 100 cattle; Daily live weight gain was the most important criterion with an importance level of 0.17 . The average life expectancy is in second place with an importance level of 0.15 , while the average birth rate is in the third place with an importance level of 0.13 . According to the rankings obtained by MOORA analysis taking into account all the criteria weights obtained, Holstein breed was the first; Simental is the second and Montafon is the third. Accordingly, it is recommended that medium-sized enterprises focus on Holstein\&Simental breeds, mainly Holstein. Businesses can also include the Montafon as a third breed if they wish.

As a result of the AHP survey conducted in enterprises with 100 cattle and more; according to the global weights obtained; The life expectancy with an importance level of 0.32 is very significant compared to other criteria. Difficult birth rate follows it with a rate of 0.15 . The average milk yield and carcass yield criteria share the third rank with 0.09 level. According to the sequence information obtained as a result of MOORA analysis; Holstein was first; the second is the Montafon and the third is Simental. It would be appropriate for large-scale enterprises to form a Holstein or Montafonbased enterprise in line with their thinking and needs. When it is desired to diversify, Simental as a third breed can be included.

According to the results, Holstein and Montafon are the most preferable breeds for the region. These breeds are followed by Simental. Balıkesir has very favorable conditions in terms of both livestock and forage crops. It is suitable for raising animal breeds more easily since it is neither too hot nor too cold for animal breeds. According to the results, support activities can be carried out in order to spread the breeds deemed suitable by breeders in the region.

This study shows that multi-criteria decision making methods, especially AHP and MOORA, can be used in decisions taken in the field of animal husbandry.

In the planning studies to be carried out according to these results, the owners will be able to give priority to the animal breeds suitable for their businesses in the selection of animal breeds.

Ways of investing in the sector should be facilitated in order to ensure development in agriculture and animal husbandry, and sustainability of the sector should be ensured by measures to protect the producer. The choice of breed for the animal to be raised for the enterprises is a medium and long-term decision. Necessary information and support should be increased at local and national level in order to ensure that cattle enterprises are directed towards medium and long-term planning.

\section{References}

[1] Tano, K., Kamuanga, M., Faminow, M. D., and Swallow, B., "Using Conjoint Analysis To Estimate Farmer's Preferences For Cattle Traits in West Afri ca", Ecological Economics, 45(3), 393-407, 2003. 
[2] Wasike, C. B., Magothe, T. M., Kahi, A. K., and Peters, K. J., "Factors That influence The Efficiency Of Beef And Dairy Cattle Recording System in Kenya: A SWOT-AHP Analysis", Tropical Animal Health And Production, 43(1), 141-152, 2011.

[3] Küçükönder, H., Efe, E., Üçkardeș, F., “Çok Ölçütlü Karar Verme Yaklașımlarından Analitik Hiyerarși Süreci'nin Hayvancılıkta Kullanımı", Iğdır Üniversitesi Fen Bilimleri Enstitüsü Dergisi, 3(3), 9198, 2013.

[4] Alitaneh, S., Naeeimipour, H., and Golsheykhi, M., "A New Idea in Animal Science: The First Application of the Analytical Hierarchy Process (AHP) Model in Selection of the Best Dairy Cow", Iranian Journal of Applied Animal Science, 5(3), 553-559, 2015.

[5] Kariuki, C. M., van Arendonk, J. A. M., Kahi, A. K., and Komen, H., "Multiple Criteria Decision-Making Process To Derive Consensus Desired Genetic Gains For A Dairy Cattle Breeding Objective For Diverse Production Systems",Journal of Dairy Science, 100(6), 4671-4682, 2017.

[6] İnal S., Akmaz, A., and Garip, M., Zootekni I: Atlas Akademi, Konya, 2016.

[7] Tiknazoğlu, B., Si.̆̆ırcılık, Samsun İl Tarım Müdürlüğ ü Çiftçi Eğitimi ve Yayım Șubesi Yayını, 1-70, 2010.

[8] Uğur, F., Sığır Yetiștirme, Çanakkale Onsekiz Mart Üniversitesi Yayınları, Canakkale, No:117, 2014.

[9] Soyak, A. Tekirdağ İli Süt Sığırcılığı İșletmelerinin Yapısal Özellikleri Ve Bu İșletmelerin Siyah Alaca Süt Sığırı Popülasyonunun Çeşitli Morfolojik Özellikleri Üzerine Bir Araștırma, Trakya Üniversitesi Fen Bilimleri Enstitüsü Zootekni Anabilim Dall, Yüksek Lisans Tezi, 2006.

[10] Et ve Süt Kurumu, Yerli ve Yabancı Süt Sığır Irkları, Holstein Siğir Irki (Siyah Alaca) https://www.esk.gov.tr/tr/10887/HOLSTEINSIGIR-IRKI-SIYAH-ALACA , 20 MAY 2019.

[11] Özçalıcı, M., Matlab İle Cok Kriterli Karar Verme Teknikleri. Nobel Akademik Yayıncılı, Ankara, 2017.

[12] Aktaș, R., Doğanay, M. M., Gökmen, Y., Gazibey, Y. and Türen, U. Sayısal Karar Verme Yöntemleri, Beta Yayıncıllk, İstanbul, 2015.

[13] Akkoç, S. and Vatansever, K., "Fuzzy Performance Evaluation With AHP And TOPSIS Methods: Evidence From Turkish Banking Sector After The Global Financial Crisis", Eurasian Journal of Business And Economics, 6(11), 53-74, 2013.

[14] Akar, C., Iș Analitiği Excel Uygulamalı Yönetsel Karar Verme ve Veri Analizi, Dora Basım Yayın Dağıtım, Bursa, 2018.

[15] Yaralığlu, K., Karar Verme Yöntemleri, Detay Yayıncilık, Ankara, 2010.

[16] Saaty, T. L., "What Is The Analytic Hierarchy Process?", In Mathematical Models For Decision Support, vol. 48, 109-121, 1988.

[17] Badri, M. A., "Combining The Analytic Hierarchy Process And Goal Programming For Global Facility Location-Allocation Problem", International Journal Of Production Economics, 62(3), 237-248, 1999.

[18] Paksoy, S. Çok Kriterli Karar Vermede Güncel Yaklașımlar. Çukurova: Karahan Kitabevi, Adana, 2017.
[19] Kuvat, Ö., "Bilgisayar Mühendisliği Öğrencilerinin Meslek Seçim Kriterlerinin AHP İle Ağırlıklandırılm ası Ve Siralanması", Yönetim ve Ekonomi Araștırmaları Dergisi, 16(3), 301-314, 2018.

[20] Brauers, W. K., and Zavadskas, E. K., "The MOORA Method and its Application to Privatization in A Transition", Economy, Control and Cybernetics, 35, 445-469, 2006.

[21] Özbek, A. Çok Kriterli Karar Verme Yöntemleri Ve Excel Ile Problem Çözümü, Seçkin Yayıncılık, Ankara, 2017.

[22] Önay O., (Editor, Yıldırım, B. F.,ve Önder, E.), Çok Kriterli Karar Verme Yöntemleri, Dora Yayıncılık, Bursa, 227-242, 2014.

[23] Ömürbek, N., and Özcan, A., "BİST'de İșlem Gören Sigorta Şirketlerinin MULTIMOORA Yöntemiyle Performans Ölçümü", Uluslararası İșletme, Ekonomi ve Yönetim Perspektifleri Dergisi, 1(2), 64-75, 2016.

[24] Kecek, G., Demirağ, F. "A Comparative Analysis of TOPSIS and MOORA in Laptop Selection", Research on Humanities and Social Sciences, 6, 1-9, 2016.

[25] Tepe, S., and Görener, A., "Analitik Hiyerarși Süreci Ve MOORA Yöntemlerinin Personel Seçiminde Uygulanması", İstanbul Ticaret Üniversitesi Fen Bilimleri Dergisi, 13(25), 1-14, 2014.

[26] Balıkesir İl Tarım ve Orman Müdürlüğü, Balıkesir İlinde Tarım Ve Hayvancılık 2018 Yılı TÜIKK Verilerine Göre Balıkesir İlinde Öne Çlkan Ürünler https://balikesir.tarimorman.gov.tr/Belgeler/Faali yet $\% 20$ Faporu/Bal\%C4\%B1kesir\%20Tar\%C4\%B1 m\%20ve\%20Hayvanc\%C4\%B1l\%C4\%B1k\%20.pdf 13.12.2019.

[27] GMKA, BALIKESİR, Tarım ve Hayvancılık Yatırım Rehberi

https://www.gmka.gov.tr/dokumanlar/yayinlar/B alikesir-Tarim-ve-Hayvancilik-Yatirim-Rehberi.pdf 13.12.2019.

[28] Israel, G. D., “Determining sample size”. Florida Cooperative Extension Service, FactSheet, PEOD-6. 5. 1992.

[29] T.C. Balıkesir Valiliği, Karesi Kaymakamlığı, İlçe Gıda Tarım ve Hayvancılık Müdürlüğü, karesi@tarimorman.gov.tr

[30] Demsa Genetik, Demsa Akademi, Sığır Irkları http://www.demsagenetik.com.tr/sigir-irklari/.20 MAY 2019.

[31] Koç. A., "Simmental Yetiștiriciliğinin Değerlendiril mesi: 2.Türkiye'deki Çalıșmalar", Adnan Menderes Üniversitesi Ziraat Fakültesi Dergisi,13(2), 103112, 2016.

[32] HAYGEM Tarım ve Orman Bakanlığı, Hayvacılık Genel Müdürlüğü, Belgeler, https://www.tarimor man.gov.tr/HAYGEM/Belgeler/Hayvanc\%C4\%B1l \%C4\%B1k/B\%C3\%BCy\%C3\%BCkba\%C5\%9F\%20 Hayvanc\%C4\%B11\%C4\%B1k/2017\%20Y\%C4\%B1 1\%C4\%B1/Damizlik Sigir_Secimi.pdf, $20 \mathrm{MAY}$ 2019. 